\title{
Evaluation of Salt-water Intrusion in the Coastal Area of Igbokoda, Southwestern Nigeria
}

\author{
*Talabi, A. $\mathrm{O}^{1}$, Ajayi, C. $\mathrm{A}^{2}$, Afolagboye, L. $\mathrm{O}^{3}$, ${ }^{1}$ Oyedele, A. $\mathrm{A}^{4}$, Ojo, O. F ${ }^{5}$, Olofinlade, S. $\mathrm{W}^{6}$ \\ 1, 2, 3, 5, 6 Department of Geology, Ekiti State University, P. M. B. 5363, Ado-Ekiti \\ ${ }^{4}$ Department of Physics, Ekiti State University, P. M. B. 5363, Ado-Ekiti \\ 1,2,3,5,6e-mails: abel.talabi@eksu.edu.ng, ajayichris00@gmail.com, afotayour@hotmail.co.uk, \\ felixfemiojo@yahoo.com, olofinladesylvester@yahoo.com \\ e-mail: akinakin02@yahoo.com \\ *Corresponding: abel.talabi@eksu.edu.ng
}

\begin{abstract}
:
Saltwater intrusion into the coastal aquifer has long been recognized as a major threat to groundwater quality around the world. Groundwater evaluation of salt water intrusions in Igbokoda coastal area, southwestern Nigeria was carried out employing combined Horizontal Profiling and Vertical electrical sounding. Two traverses each with two sounding points were occupied. The result from the survey revealed 4 to 5 major layers comprising the unconsolidated silty sand and sandy clay (overburden), clayey zone, consolidated sand zone, partly intruded salt water intruded sandy clay zone and salt water intruded clay zone. The curves were the complex types KQH, KHA, QH and HKH curves. The overburden has resistivity that ranged from 253 to $1316.7 \Omega-\mathrm{m}$, thickness that ranged from $0.2 \mathrm{~m}$ to $7 \mathrm{~m}$. The clayey zone had resistivity of $846.0 \Omega-\mathrm{m}$ and thickness of $4 \mathrm{~m}$. The consolidated sand zone had resistivity that ranged from 2848.7 to $2865.7 \Omega-\mathrm{m}$ and thickness that ranged between 4 and $21 \mathrm{~m}$. The partly intruded salt water zone is characterized by resistivity that varies between $18.4 \Omega-\mathrm{m}$ and $93.0 \Omega-\mathrm{m}$ and thickness of about 7 $25 \mathrm{~m}$. The salt water intruded zone is characterized by resistivity that ranges between $4.1 \Omega-\mathrm{m}$ and $9.7 \Omega-\mathrm{m}$ and thickness of $4-48 \mathrm{~m}$. The partly-salt water intruded zones and salt water intruded zone were characterized with low resistivity while the high resistivity zones of consolidated sand layer constitute fresh water bearing zone that could serve as boreholes in the study area.
\end{abstract}

Keywords: Groundwater quality, sounding points, salt water intrusion, consolidated sand, resistivity.

\section{Introduction}

Saltwater intrusion into the coastal aquifer, a phenomenon brought by the flow of seawater into freshwater aquifers originally caused by groundwater extraction near the coast, has long been recognised as a major concern around the world [1, 2]. Almost two thirds of the world's population are said to be living within $400 \mathrm{~km}$ of the ocean shoreline and just over half live within $200 \mathrm{~km}$, an area only taking up $10 \%$ of the earth's surface [3]. These coastal dwellers depend largely on groundwater as main source of fresh water for daily survival, industrial and agricultural purposes; a development that could lead to excessive groundwater extraction. The induced gradients usually cause migration of salt water from the sea toward a borehole where groundwater is being pumped from aquifers that are in hydraulic connection with the sea [4]. This will definitely make the freshwater in the well unusable and thus hamper the development of potable water for municipal use. Successful management of coastal groundwater resources depends not only upon planning and regulation, but also on the accurate assessment and prediction of the behavior of the saltwater interface to both natural conditions and man's activities [5]. In Nigeria, there have been few studies mostly by University Researchers aimed at assessing fresh water resources in coastal areas with regards to salt water intrusion. The investigation of seawater intrusion in freshwater aquifers in the proximity of seas has been based on geophysical techniques especially the electrical resistivity and electromagnetic methods which relies on resistivity contrasts as the seawater intruded zone is approached, [6]. The presence of seawater causes groundwater to be considerably saline, hence the aquifer resistivity is reduced considerably, and the resistivity method can delineate the boundaries of 
the body of saline water. The fact that a resistivity contrast exists at the interface between fresh and saline water is sharp, the resistivity method has proved useful. Basically, fresh water is less dense than salt water and so it floats on top. Therefore, saline water is found below fresh water discharge from higher altitude in coastal areas. Also, the boundary between salt water and fresh water is not distinct; the zone of dispersion, transition zone, or salt-water interface is brackish with salt water and fresh water mixing. It then means that salinity will increase with depth where both fresh water and saline water occur. As such, the increase in salinity will produce consequent decrease in electrical resistivity of water and thus resistivity varies with depth within groundwater well in coastal aquifer [7]. In addition, the resistivity of ground water varies from 10 to $100 \mathrm{ohm} \bullet \mathrm{m}$. depending on the concentration of dissolved salts. Note the low resistivity (about $0.2 \mathrm{ohm} \bullet \mathrm{m}$ ) of sea water due to the relatively high salt content. This makes the resistivity method an ideal technique for mapping the saline and fresh water interface in coastal areas [8]. Thus, electrical resistivity survey method that is capable to identify zones and interfaces of salt intrusion and gives insight to locations and depths to which borehole wells can be drilled to contact nonintruded/uncontaminated fresh water zone is employed to evaluate salt water intrusions into the coastal aquifer of Igbokoda.

\section{Location, geology/hydrogeology of study area}

Igbokoda town extends from latitude $6^{\circ} 20^{\prime} \mathrm{N}$ to $6^{\circ} 24^{\prime} \mathrm{N}$ and longitude $4^{\circ} 45^{\prime} \mathrm{E}$ to $4^{\circ} 48^{\prime} \mathrm{E}$ (Fig. 1). The town is about $24 \mathrm{~km}$ from the coast of Atlantic Ocean. Igbokoda is located on lowland area with elevation of $<15 \mathrm{~m}$ above sea level. The area has low land tropical rain forest climate with mean annual rainfall that exceeds $2000 \mathrm{~mm}$ and average monthly temperature of $27^{\circ} \mathrm{C}$. Igbokoda coastal zone is located within the eastern part of Dahomey sedimentary basin, a coastal zone endowed with abundant important raw materials including the high quality silica sand that is used in glass sheet production, crude oil that constitute the main source of revenue for Nigeria as well as large deposit of untapped bitumen. The coastal zone has one of the largest fish terminals in Nigeria in addition to oil palm production, alcohol distillery and palm wine tapping industries.The area is covered by sedimentary rocks that are mainly of the post Cretaceous sediments and the Cretaceous Abeokuta Formation. It consists of the coastal sand bars that stretch in a NW - SE direction from Okitipupa to the Atlantic Ocean. The area is covered mainly by Quaternary alluvium deposits underlain virtually in all places by the Quaternary coastal plain sands (Fig 1) [9]. The coastal plain sands constitute the major shallow hydrogeological units and adequate annual recharge is guaranteed considering the high annual rainfall and other favourable climatic conditions. The Imo Shale Group that lay below coastal sands contains thick layers of porous but impermeable shale thus making the groundwater yielding capacity to be of a very low rating. However, limited groundwater yield could be obtained from lenses of sand/sandstone within the shale. Within the Upper Coal Measures, lenses of sand, dissolved or fractured limestone constitute the aquifer units. Limited groundwater yield is expected from the lenses of sand. Groundwater potential is also adjudged low. The Nkporo Shale has lenses of sand as its aquifer unit. Within the Nkporo Shale, thin layers of sand constitute the aquifer units with consequently low groundwater potential [10].

\section{Methodology}

Electrical resistivity profiling (HP), also known as Constant separation transversing (CST) and Vertical Electrical resistivity sounding (VES) were employed for this study using Omega Campus SAS 1000. The HP method has sounding capability as well as profiling applications. For these combined VES/CST surveys, the data are plotted in pseudo-section as apparent resistivity in order to look for anomalous regions. Data HP discriminates lateral variation in the subsurface and therefore provides needed locations for VES. VES method gives the information about depth and thickness of various subsurface layers and their potential for groundwater exploitation as well as discriminating groundwater pollution. In the first method (HP), the electrode spacing was fixed at $10 \mathrm{~m}$ and the array of electrodes was moved laterally along a profile with constant separation, the apparent resistivity's being plotted at the midpoints. In the second type of measurement the center of the electrode spread remains fixed but the separation of electrodes was increased 


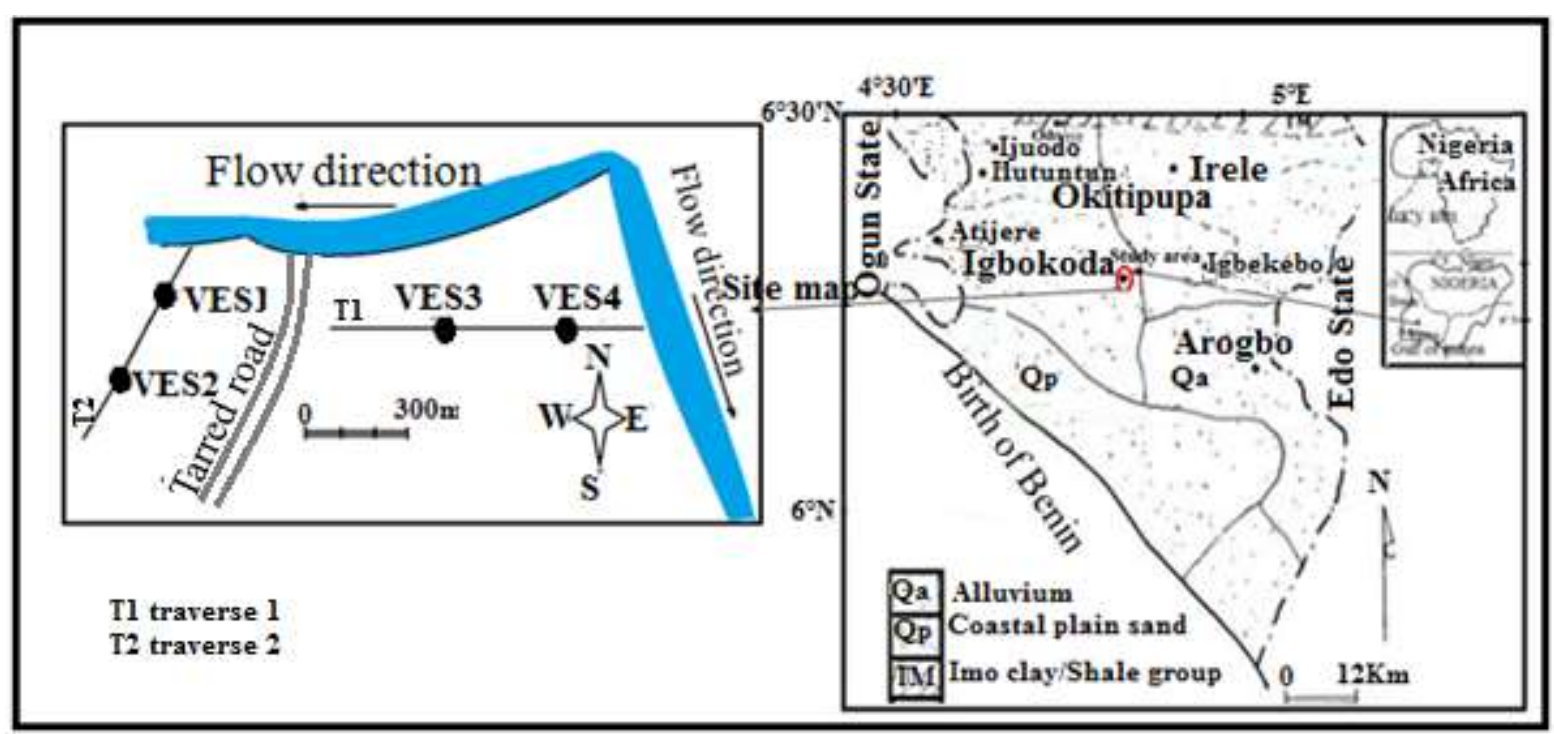

Fig. 1. Geology and Location of Study

progressively. The depth to which information was obtained was approximately the same as the electrode separation in the Schlumberger arrangement. The convention for dipole-dipole array is that current and potential electrode spacing is the same, a, and the spacing between them is an integral multiple of a, na. The apparent resistivity is thus given by

$\rho_{\mathrm{a}}=\mathrm{V} / \mathrm{I} \operatorname{\pi an}(\mathrm{n}+1)(\mathrm{n}+2)$

The data obtained from the dipole-dipole survey are processed by creating a pseudo-section of the apparent resistivity values using DIIPRO software. Computer iterations were then carried out and two dimensional (2-D) resistivity contour maps were created.Data obtained for VES soundings were interpreted using RESIST software. The curves resulting from the data upon interpretation give thickness and resistivity of various layers. Consequently, parameters such as layer resistivity, layer thickness and number of layers for each VES point were obtained and presented in the section of results and discussion. After the interpretation of the resistivity curves, the resulting model parameters i.e. layer resistivity and thicknesses were used to prepare geoelectric sections from which areas affected by salt-water could be delineated.

\section{Results and Discussion}

Two electrical resistivity methods; horizontal profiling and vertical electrical sounding were employed in this study using dipole-dipole and Schlumberger arrays respectively. The results of each respective survey methods were evaluated and represented inform of curves and geo-electric sections.

\subsection{Horizontal profiling system}

A total of 2 traverses spanning between $150-210 \mathrm{~m}$ with dipole-dipole electrode spacing of $10 \mathrm{~m}$ were occupied during this survey. The raw data obtained from field was used in preparing results presented in form of field, theoretical and 2D imaging resistivity pseudo structures shown in figures 2 and 3 for the traverses. The pseudo structures reveal image of the subsurface lithologies in the study area showing variations in the vertical and lateral resolution of the subsurface. In traverse 1, 3 geoelectric layers were delineated (blue, green and yellow zones) (Fig.2). The geoelectric layer designated by blue represents clayey/salt water intruded formation, the green colour band signifies partly-salt water intruded zones while yellow colour bands are the brackish water zone. The brackish water zone with high resistivity values having sandy lithology covered the near surface area spanning between 20 to $85 \mathrm{~m}$ upto depth of $5 \mathrm{~m}$ wheras the partly intruded salt zone and 
salt intruded zone with sandy/clayey and clayey lithologies respectively covered most of the area.

In traverse 2, four geoelectric layers are delineated

(Fig.3). They are the zones characterized with low
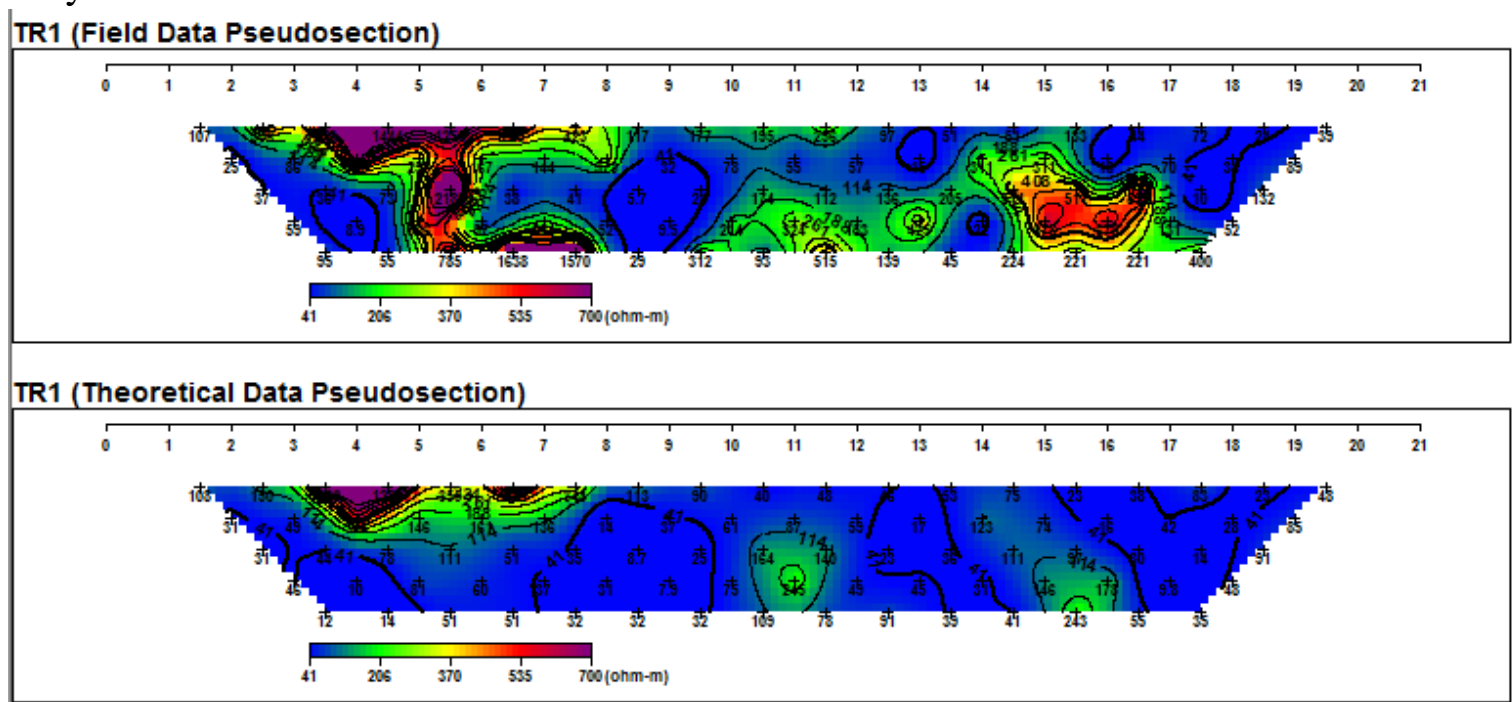

TR1 (2-D Resistivity Structure)

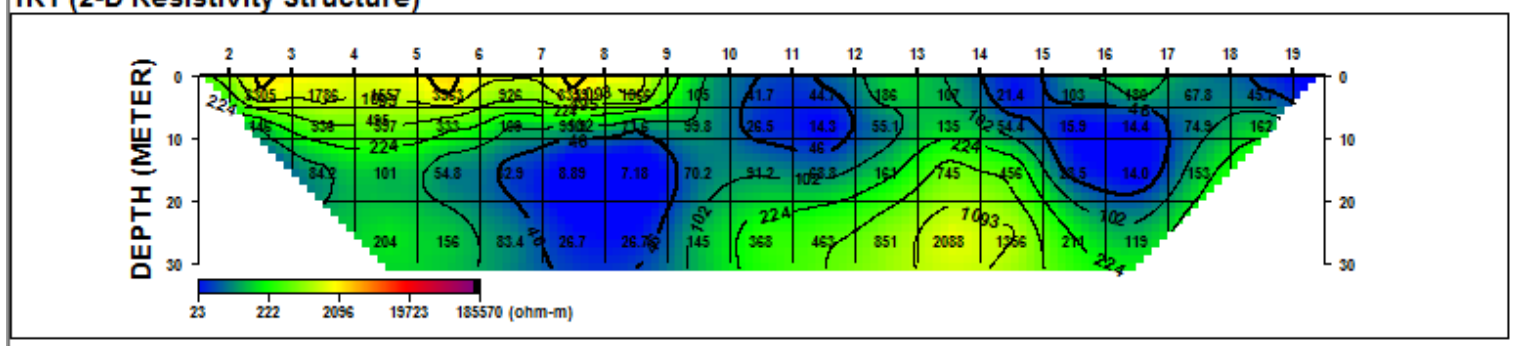

Figure 2 : 2D Resistivity Pseudo-section along Traverse 1

intruded formation, light-greenish colour bands as the partly-salt water intruded zones, moderately high resistivity values of yellowish as brackish water zone which can be said to be a transition between the salt and fresh water. High resistivity values of reddish colour band are the fresh water zone. Low resistivity values are observed between distances 90$200 \mathrm{~m}$ as near surface materials to a depth of 10 metres; which indicates that clayey materials characterized the topsoil of that section along traverse 2 of the study area. Low resistivity values were also observed between distances 43-68m within a depth of $11-28 \mathrm{~m}$ and distance $80-110 \mathrm{~m}$ within a depth of $20-60 \mathrm{~m}$ shows zones of possible salt-water intrusion as a result of extremely low resistivity values compared to the other parts of the sandstone stratum formations. The sandstone is observed within distances 140-180m within a depth beyond $15 \mathrm{~m}$. The partly intruded salt water zone and salt water intruded zone occupies almost $50 \%$ of the study area occurring at different locations with relatively low resistivity while the consolidated sandy zone of relatively high electrical resistivity value occurs from depth of $3.4 \mathrm{~m}$ in traverse 1 and depth greater than $20 \mathrm{~m}$ in traverse 2. This consolidated sandy zone of high resistivity zone in traverse 2 can be prospected for fresh water occurrence due to its considerable thickness.

\subsection{VES resistivity method}

A total of 4 VES locations across 2 traverses were spread over the study area (Fig. 1). The processed data were interpreted, resulting curve types were categorized, existing subsurface lithologic units were established and the geoelectric properties of the various subsurface layers were used in delineating the salt water intruded zone in the study area. The results are presented in the form of table (Table 1), geoelectric curves (Fig. 4) and sections (Figs. 5a and $5 b)$. The main curve types in the sounded stations are KQH, KHA, QH and HKH curves (Fig.4). The curves and geo-electric sections gave information about the subsurface of the lithology of the study area. Five lithologies were revealed in VES1, 2 and 4 while four lithologies were encountered in VES 3. The lithologies were characterized with 
International Journal of Scientific Research and Management (IJSRM)

|Volume||06||Issue||01||Pages ||G-2018-01-08||2018\|

Website: www.ijsrm.in ISSN (e): 2321-3418

Index Copernicus value (2015): 57.47, (2016):93.67, DOI: 10.18535/ijsrm/v6i1.g01

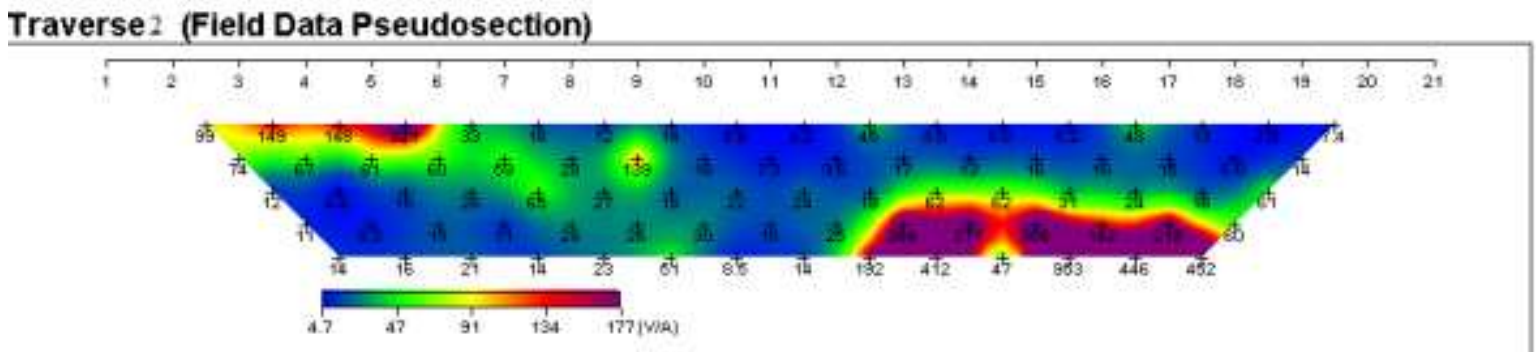

Traverse2 (Theoretical Data Pseudosection)

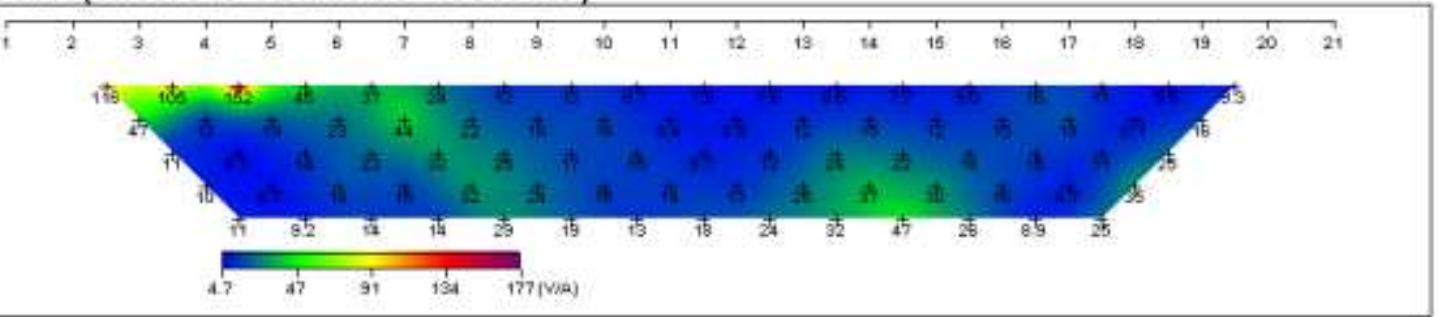

Traverse (2-D Resistivity Structure)

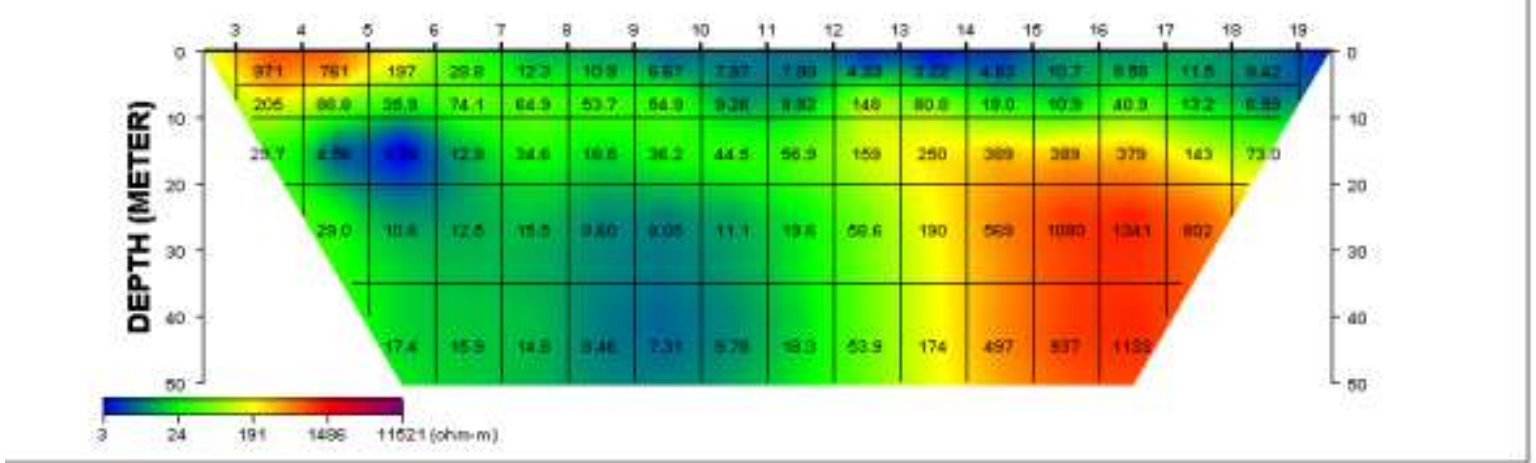

Figure 3: 2D Resistivity Pseudo-section along Traverse 2

Table 1: Correlation Table

\begin{tabular}{|c|c|c|c|c|c|c|}
\hline VES No. & Layer & Curve type & Resistivity ( $\Omega-m)$ & Thickness(m) & $\operatorname{Depth}(\mathrm{m})$ & Lithology \\
\hline \multirow[b]{5}{*}{1} & 1 & & 736.4 & 0.9 & 0.9 & Sily clay \\
\hline & 2 & & 2865.7 & 2.4 & 3.4 & Consolidated sand \\
\hline & 3 & & 40 & 3.7 & 7.1 & Sandy/clayey \\
\hline & 4 & & 4.1 & 24.3 & 31.3 & Clay \\
\hline & 5 & KQH & 68.2 & - & - & Sandy/clayey \\
\hline \multirow[b]{5}{*}{2} & 1 & & 1316.7 & 2.8 & 2.8 & Sandy clay \\
\hline & 2 & & 452 & 2 & 4.8 & Unconsolidated sand \\
\hline & 3 & & 22.5 & 12.3 & 17.1 & Sandy/clayey \\
\hline & 4 & & 92.7 & 8.1 & 25.3 & Sandy/clayey \\
\hline & 5 & KHA & 1152.6 & - & - & Sandy clay \\
\hline \multirow[b]{4}{*}{3} & 1 & & 288.2 & 1.2 & 1.2 & Unconsolidated silty sand \\
\hline & 2 & & 18.4 & 13.3 & 14.4 & Sandy/clayey \\
\hline & 3 & & 9.7 & 16.7 & 31.3 & Clay \\
\hline & 4 & QH & 13 & & & Sandy/clayey \\
\hline \multirow{5}{*}{4} & 1 & & 253 & 0.7 & 0.7 & Unconsolidated sand \\
\hline & 2 & & 32 & 1.6 & 2.3 & Sandy/clayey \\
\hline & 3 & & 846 & 1.3 & 3.6 & Clay \\
\hline & 4 & & 25.3 & 18.7 & 22.3 & Sandy/clayey \\
\hline & 5 & HKH & 2848.7 & & $\ldots$ & Consolidated sand \\
\hline
\end{tabular}

unconsolidated silty sand and sandy clay clayey (intruded salt water zone) sand/clayey layer representing overburden layer, consolidated sand, (partly-salt water intruded zones. The salt water 
intruded zone is characterized by low resistivity. The overburden was thin in most sounding point i.e less than $7 \mathrm{~m}$ and with resistivity that ranged from 253.0 $1316.7 \Omega-\mathrm{m}$, the low resistivity zones delineating partly-salt water intruded zones and salt water intruded zones with thickness between $4-48 \mathrm{~m}$ and resistivity that ranged from 4.1-92.7 $\Omega-\mathrm{m}$ while the high resistivity zones of consolidated sand layer had resistivity that ranged from 2848.7-2865.7 $\Omega$-m and thickness between 4 and over $20 \mathrm{~m}$ as it occurs as basement in station 4 (Fig.5).

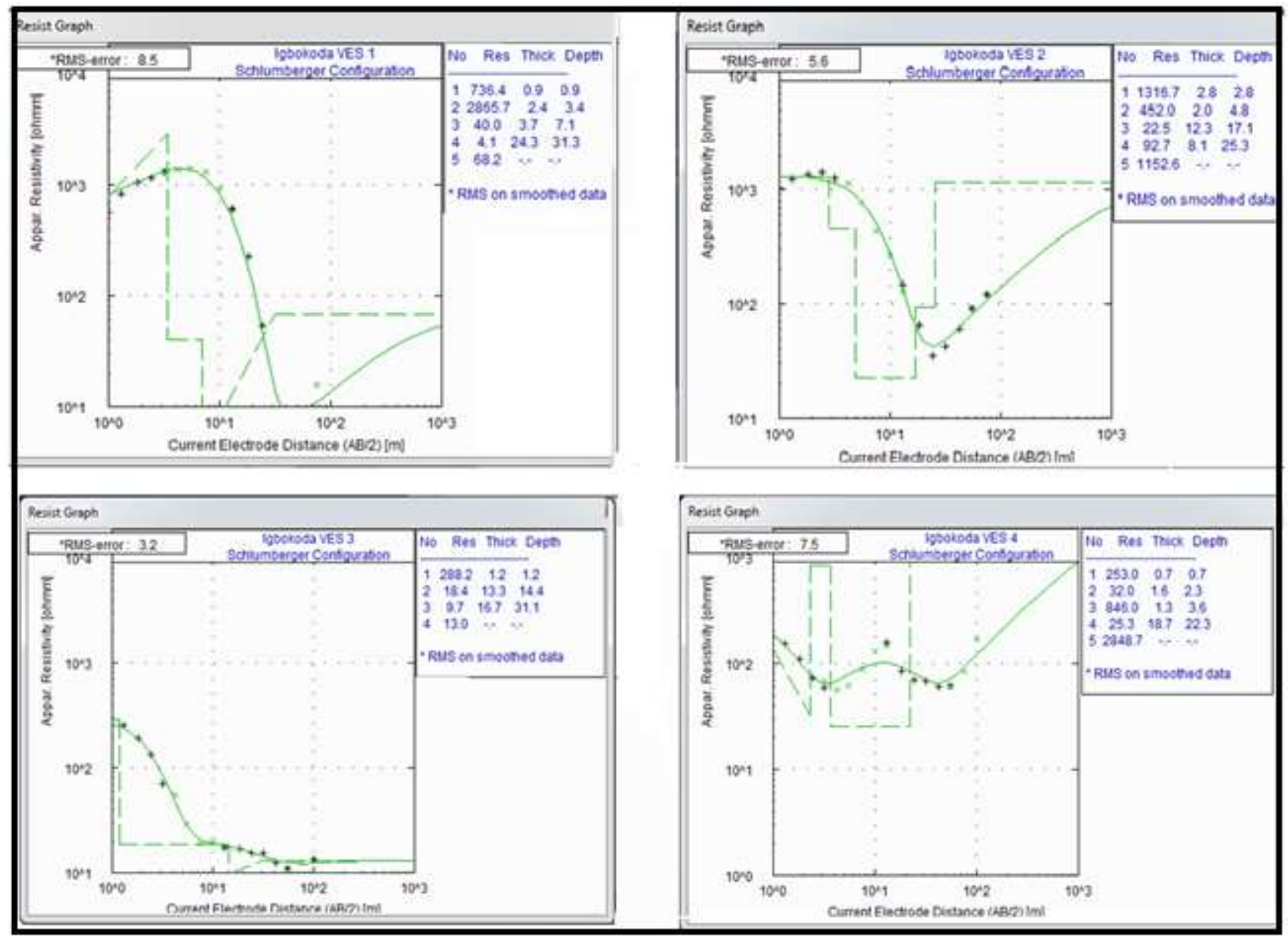

Fig 4: Typical Geoelectric Curves from data Interpretation

\section{Conclusion}

In this study, Evaluation of Salt-water Intrusion in the Coastal Area of Igbokoda, Southwestern Nigeria was carried out employing profiling and four Schlumberger vertical electrical soundings (VES). The curves were the complex types KQH, KHA, QH and HKH curves. The computer assisted profiling and sounding interpretation revealed five different subsurface lithologic sequences namely; silty sand, sand, sandy clay, clay and sandy clay. The overburden was thin in most sounding point $<7 \mathrm{~m}$ and with resistivity that ranged from 253.0-1316.7 $\Omega$ $\mathrm{m}$. The overburden serves as fresh water aquifer constituting shallow groundwater of the study area. The partly-salt water intruded zones and salt water intruded zone were characterized with low resistivity while the high resistivity zones of consolidated sand layer constitute fresh water bearing zone that could serve as boreholes in the study area. 


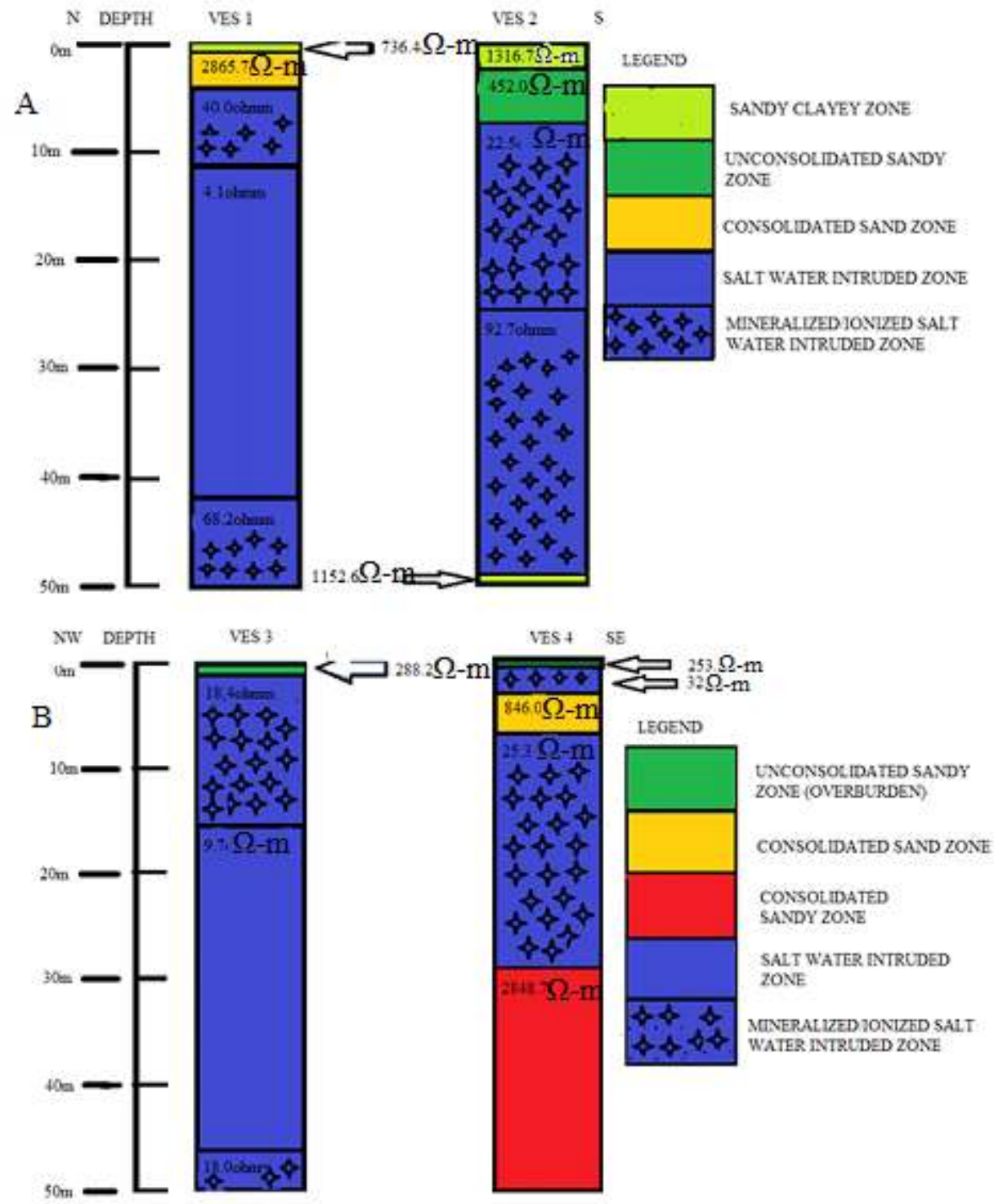

Fig. 5 : Geo-electric sectionof VES 1, 2, 3 and 4 of Igbokoda coastal area.

\section{References}

1. Al Barwani, T. Helmi, Seawater intrusion in a coastal aquifer: a case study for the area between Seeb and Suwaiq in the Sultanate of Oman. Agric Mar Sci. 11:55-69, 2006.

2. .A. Ayolabi, A.F, Folorunso, A.M, Odukoya, A.E. Adeniran, Mapping saline water intrusion into the coastal aquifer with geophysical and geochemical techniques: the University of Lagos campus case (Nigeria). Springerplus. 2: 433. Published online 2013 Sep 4. doi: 10.1186/2193-1801-2-433.

3. Hinrichsen, Ocean Planet in Decline. 2007. [People and the Planet] Available: [online] http://www.peopleandplanet.net/?lid=26188 \&topic $=44 \&$ section $=35$.
December. 22, 2017].

4. .A.E. Abdalla, M. Ali, K. Al-Higgi, H. AlZidi, I. El-Hussain, S. Al-Hinai, Rate of seawater intrusion estimated by geophysical methods in an arid area. Hydrogeology J. 18:1437-1445, 2010. doi: 10.1007/s10040010-0606-0.

5. L. Yuhr, R.C. Benson, "Saltwater intrusion: concepts for measurements and a regional characterization for Broward County, Florida" Proc. Symp. On the application of geophysics to engineering and environmental problems, 231 - 242, 1995.

6. M. Goldman, A. Arad, U. Kafri, D. Gilad, A. Melloul, Detection of freshwater/seawater interface by the Time Domain 
Electromagnetic (TDEM) method in Israel. In: Proc. 10 ${ }^{\text {th }}$ SWIM, Ghent, 329-344, 1989.

7. Nwankwoala, H.O. Coastal Aquifers of Nigeria: an overview of its management and sustainability considerations. Journal of applied technology in environmental sanitation.Vol.1.No4, pp371 - 380, 2011.

8. M.H. Loke, Electrical imaging surveys for environmental and engineering studies: A practical guide to 2-Dand 3-D surveys, 2000.

9. A.O. Talabi, Implications of Excess Iron in the groundwater of Igbokoda Areas, SW Nigeria. Elixir Earth Sci. 89, 36699-36703, 2015.
10. G.O. Omosuyi, Geophysical and Hydrogeological investigations of Groundwater prospects in the southern part of Ondo State, Nigeria, Ph.D. Thesis, Department of Applied

11. Geophysics, Federal University of Technology Akure, Nigeria, (Unpubl.), p195, 2001. 